\title{
EFFECTS OF ASCORBIC ACID, TRANSLUTAMINASE AND MARGARINE AMOUNTS ON THE QUALITY OF PUFF PASTRY MADE FROM SPELT FLOUR
}

\author{
Olivera D. Šimurina ${ }^{1 *}$, Bojana V. Filipčev ${ }^{1}$, Marija I. Bodroža-Solarovv ${ }^{1}$, Dragana M. Šoronja-Simovićc \\ ${ }^{1}$ University of Novi Sad, Institute of Food Technology, Bulevar cara Lazara 1, 21000 Novi Sad, Serbia \\ ${ }^{2}$ University of Novi Sad, Faculty of Technology, Bulevar cara Lazara 1, 21000 Novi Sad, Serbia
}

*Corresponding author
Phone: +381214853778
Fax: +38121450725
E-mail address: olivera.simurina@fins.uns.ac.rs

ABSTRACT: Puff pastry has delicate and flaky texture which comes from unique combination of fat and dough. These bakery products are made from many thin layers of dough which are separated by alternate fat layers because of which they are considered to be high fat food. Properties of puff pastry depend mostly on the quality of flour, which must be specifically tailored for this purpose. The most commonly used flour in the production of puff pastry is refined wheat flour. Lately, the requirements of consumers for healthy bakery products have a great response in the baking industry. On the market there are new products made with ingredients which have high nutritional value. This paper presents an optimization of the composition of puff pastry made of spelt flour by varying the amount of ingredients such as: margarine, ascorbic acid and enzyme transglutaminase. The optimal ratio of these ingredients has been based on the consideration of their major and interaction effects. During the optimization of spelt puff pastry quality, the following goals were set: maximum volume, minimum firmness and maximum overall acceptability. The optimal solutions were in the concentration range from $3.60 \mathrm{mg} / \mathrm{kg}$ to $10 \mathrm{mg} / \mathrm{kg}$ for ascorbic acid, from $0.03 \mathrm{mg} / \mathrm{kg}$ to $3 \mathrm{mg} / \mathrm{kg}$ for transglutaminase and from 29.84 to $30 \%$ for margarine on dough basis. It is recommended that the composition of spelt puff pastry involve: $10 \mathrm{mg} / \mathrm{kg}$ ascorbic acid, $0.03 \mathrm{mg} / \mathrm{kg}$ transglutaminase and $30 \%$ margarine on dough basis to provide the desired product characteristics.

Key words: spelt, puff pastry, ascorbic acid, transglutaminase, optimization

\section{INTRODUCTION}

Puff pastry is a non-yeasted, laminated bakery product made from many thin layers of dough which is separated by alternate fat layers. The unique combination of fat and dough of puff pastry gives them their light, delicate and flaky texture, which adds a characteristic and highly desirable sensory enhancement (Wickramarachchi et al., 2015). Puff pastry making is a complicated process that involves widely varying production practices and the making of puff pastry still remains an art. The production process depends on the quantity of two main ingredients: flour and fat.
Flour and fat must be of a tailored quality with specific characteristics (Wickramarachchi et al., 2015).

Two types of fat are used in puff pastry production: 'shortening' in relatively small quantities to improve the dough properties, and the puff pastry margarine (Bessler and Ortheoefer, 1983, Lefébure et al., 2013). Margarine has essential functions in the puff pastry preparation, which is mainly to separate the dough layers and to trap the water that evaporates in the oven, which leads to an expanded final product. The bakers typically use a fat 
content varying from $50 \%$ to $100 \%$ on flour basis in the recipes of puff pastry and the finished product can contain $30 \%$ or more fat on a weight basis (Soronja Simovic et al., 2009), and hence, it is considered to be a high fat food (Bakal, 1991). The high fat content in the puff pastry is necessary, because the role of the fat is to provide puffiness to the product. Another important raw material in the production of the puff pastry is flour. The bakers commonly use the flour protein content as the primary criterion for selecting the type of flour to be used for puff pastry (Hay, 1993).

Many researchers found that the rheological quality of the gluten protein is of greater importance than the protein content of the flour (Wickramarachchi, 2015). It is generally accepted that strong flours give increased lift (Taylor, 1985) and weak flours have low lift which could be due to destruction of the layers early in lamination, resulting in poor gas retention and low pastry lift (Wickramarachchi, 2015).

Increased consumer concern over the use of high fat amounts (Wassell and Young, 2007) and refined flour in the production of puff pastry has increased pressure on the bakery industry to produce low-fat products with flour of more nutritious value. Flour from spelt wheat is one of such ingredients. The nutritive value of spelt wheat is high and it contains all the basic components which are necessary for human beings (Bojnanská and Francáková, 2002). It was also found that spelt wheat contains more protein than common wheat and that the amino acid composition of the proteins from spelt differs slightly from the modern wheat. Furthermore, the lysine is assimilated better from spelt than from the common wheat. Spelt wheat has been widely used in the production of various products such as: bread, composite breads, cookies, pasta, flakes, cracker etc. (Abdel-Aal et al., 1998; Marconi et al., 2002, Filipčev et al., 2012; 2014).

The idea of our research group was to apply the spelt flour in the production of puff pastry, at the same time taking into consideration that this cereal shows be- havior different from convenient wheat in baking (Schober et al., 2002). The dough made from spelt flour is characterized by lower stability, less elasticity, and higher extensibility than the one in the common wheat dough. The spelt dough is very soft and sticky after kneading. Technological treatment of flour from spelt wheat requires the addition of ascorbic acid in comparison with flours from the common wheat, because of the strength of the gluten structure and the reduction of dough extensibility (Bojnanská and Francáková, 2002).

It is also known that the enzyme transglutaminase has the role of the dough strengthening improver. That is why this study included additives such as: ascorbic acid and enzyme transglutaminase. To our knowledge, there are several studies which show that the formulation is a key factor affecting the final product quality. Therefore, this research aimed to determine effects of ascorbic acid, transglutaminase and puff pastry margarine amount on the physical and textural quality of puff pastry made of spelt flour, and to optimize its formulation.

\section{MATERIALS AND METHODS}

\section{Raw material}

Refined spelt wheat flour was obtained from the Jevtić organic farm (Bačko Gradište, Serbia). The chemical characterristics of the flour were: the moisture content $13.34 \%$, the ash content $1.20 \%$ on dry basis, protein content $\left(\mathrm{N}^{\star} 5.7\right) 15.81 \%$ on dry basis, wet gluten $40.8 \%$ and $51.4 \%$ water absorption according to farinograph, was used for all formulations. Margarine Argentina Pastry HF (Puratos, Belgium) was used as dough fat. The Lascorbic acid was purchased from BASF, Germany. Transglutaminase (VERON ${ }^{\circledR} \mathrm{TG}$ $100 \mathrm{U} / \mathrm{g}$ ) was obtained from $A B$ Enzymes (ABF Ingredients, Darmstadt, Germany).

\section{Physicochemical analysis of raw materials}

Wheat flour was analysed for moisture, ash, protein, gluten and farinograph water absorption according to standard AACC procedures 44-19, 08-01, 46-12, 38-10 and 54-21 respectively (AACC, 1995). 
Table 1.

The basic recipe of the spelt puff pastry

\begin{tabular}{ll}
\hline Applied ingredients & Amount $(\mathbf{g})$ \\
\hline Spelt flour & 1000 \\
Salt & 20 \\
Water & 480 \\
Ascorbic acid & According to experimental design \\
Transglutaminase & According to experimental design \\
Margarine & According to experimental design \\
\hline
\end{tabular}

\section{Pilot production of puff pastry}

The dough was mixed in a laboratoryscale Diosna mixer (Dierks \& Söhne $\mathrm{GmbH}$, Osnabrück, Germany) at low speed $(85 \mathrm{rev} / \mathrm{min})$ for $1 \mathrm{~min}$ and at high speed (120 rev/min) for $4 \mathrm{~min}$. The dough formulation of the spelt puff pastry is shown in Table 1.

The final dough temperature was in the range of about $21 \pm 1^{\circ} \mathrm{C}$. The dough was sheeted on a Pastry Sheeter Model MK 500-600 (Mac. Pan, Italy) to a thickness of about $10 \mathrm{~mm}$.

The puff pastry margarine (amount according experimental design) is sheeted to the same thickness and placed into the dough sheet according to English method (Mc Gill, 1981).

The dough was laminated to a thickness of about $10 \mathrm{~mm}$, folded by one three-fold (1x3) and re-rolled to $10 \mathrm{~mm}$. The dough is then folded into fourths $(1 \times 4)$ and then was refrigerated at $5{ }^{\circ} \mathrm{C}$ for $20 \mathrm{~min}$. These steps are repeated twice to generate 144 theoretical fat layers.

The pastry sheet of final thickness $10 \mathrm{~mm}$ was cut into quadrate dimensions: $60 \mathrm{~mm}$ x $60 \mathrm{~mm}$ x $60 \mathrm{~mm}$, weight $35 \pm 1 \mathrm{~g}$. The dough pieces were allowed to rest for 10 min at the room temperature, and then baked for $15 \mathrm{~min}$ at $220^{\circ} \mathrm{C}$.

After cooling, the baked pastry pieces were evaluated for volume, texture and sensory properties. The volume of the loaves was assessed by means of laser measuring device Volscan profiler 600 (Stable Micro Systems, England).

\section{Texture analyses of puff pastry}

The texture analysis of puff pastry was carried out $2 \mathrm{~h}$ after baking by cutting with Extended Craft Knife A/ECB on a TA.XT2 Texture Analyzer (version TA.XTPlus, Stable Micro Systems Ltd., Surrey, UK).

The measured parameter was firmness, which was obtained from compression curve. The test was conducted under the following settings: pretest speed $1.0 \mathrm{~mm}$ $\mathrm{s}^{1}$, test speed $2.0 \mathrm{~mm} \mathrm{~s}^{-1}$, post-test speed $10.0 \mathrm{~mm} \mathrm{~s}^{-1}$, distance $55 \mathrm{~mm}$.

\section{Sensory evaluation}

Sensory evaluation was conducted according to procedure by Soronja Simović et al. (2009).

\section{Experimental design and statistical methods}

Box and Behnken experimental design was used to highlight the main and interactive effects of ascorbic acid, transglutaminase and margarine on volume, firmness and overall acceptability of puff pastry, allowing a maximum of information out of a minimum number of experiments (Box and Behnken, 1960). Three factors were considered, at 3 levels for each factor $(-1$ for the lowest value of the factors; 0 for medium value of the factors; and +1 for the highest value of the factors), as presented in Table 2.

Statistical data analysis was performed by response-surface methodology using the Design-Expert 8.1 (Stat-Ease Corporation, Minneapolis, MN, USA).

For responses (volume- $V$, firmness- $F$ and overall acceptability-OA), a quadratic model was applied (eqn. 1):

$$
Y=b_{0}+b_{1} X_{1}+b_{2} X_{2}+b_{3} X_{3}+b_{11} X_{1}^{2}+b_{22} X_{2}^{2}+b_{33} X_{3}^{2}+b_{12} X_{1} X_{2}+B_{13} X_{1} X_{3}+B_{23} X_{2} X_{3}
$$


The models were tested for adequacy using the ANOVA through the coefficient of determination $\left(R^{2}\right)$ and $F$-values. The significance of regression coefficients was assessed by $p$-values at the three significance levels $(p \leq 0.01 ; p \leq 0.05 ; p \leq 0.1)$. In order to achieve the visual effects of the independent variables on the rheological parameters of the dough, the perturbation graphs are shown for each parameter. Numerical optimization was based on the desirability function (Derringer and Suich, 1980). The desirability function approach was used to assess the amount of ascorbic acid, transglutaminase and margarine needed to achieve maximum volume, minimum firmness and the best overall acceptability of the puff pastry made from spelt flour.

\section{RESULTS AND DISCUSSION}

Results of the experimental design referring to volume $(\mathrm{V})$, firmness $(\mathrm{F})$ and overall acceptability (OA) of the puff pastry made from spelt flour with different concentration of ascorbic acid (AA), transglutaminase (TG) and margarine (M) are shown in Table 3.

The results of the experimental design (Table 3) showed that the greatest volume $(\mathrm{ml})$ and the overall acceptability of the puff pastry were achieved in the experiment 13 due to synergistic effects of ascorbic acid and transglutaminase with addition of margarine in maximum amount. It is expected that the final product with the highest volume, which is, actually, the biggest puffiness, has the greatest acceptability by sensory assessors. The value of firmness decreased with the increase of the amount of the ascorbic acid and with the decrease of the amount of trans- glutaminase, while the amount of margarine remained on the same maximum level of $30 \%$ on dough basis. The greatest score for the overall acceptability was obtained for formulation 13, which included ascorbic acid and transglutaminase with the maximal amount of margarine. The lowest score was registered in formulation 14 , which excluded the tested improvers. The results showed that in the formulation for the puff pastry made from spelt, it is necessary to include ingredients with oxidation effect.

The main and the interaction effects of ascorbic acid, transglutaminase and margarine on the selected properties of puff pastry made from spelt flour are presented via regression coefficient values which are given in Table 4.

Based on the results shown in Table 4, it can be stated that all ingredients had an important influence on the volume of the spelt puff pastry. Margarine exerted the largest and the most important effect on the increase in volume of the product. The combination of ascorbic acid and margarine had also positive effect on the volume of product, but in a lesser amount, thus it is less important. The ascorbic acid and transglutaminase individually did not have an important influence on the volume, but in combination, they considerably contributed $(p \leq 0.01)$ to a decrease in the volume, which was expected, considering the oxidation effect of both additives.

When they were combined, their oxidation effect significantly influenced an increase $(p \leq 0.05)$ in the firmness of product, which is reflected in the decrease of the overall acceptability of product.

Table 2.

Box and Behnken experimental design

\begin{tabular}{|c|c|c|c|c|}
\hline & \multirow{2}{*}{ Independent factors } & \multicolumn{3}{|c|}{ Coded values } \\
\hline & & -1 & 0 & +1 \\
\hline \multirow{2}{*}{ 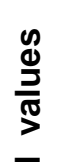 } & Ascorbic acid, g/ $/^{*} 100 \mathrm{~kg}$ & 0.0 & 5.0 & 10.0 \\
\hline & Transglutaminase, $\mathrm{g} /{ }^{*} 100 \mathrm{~kg}$ & 0.0 & 1.5 & 3.0 \\
\hline 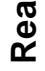 & Margarine, $\%{ }^{* *}$ & 15.0 & 22.5 & 30.0 \\
\hline
\end{tabular}

${ }^{*}$ spelt flour; ${ }^{* *}$ the amount of margarine expressed in \% on dough basis 
Table 3.

Results of the effects of ascorbic acid, transglutaminase and margarine in different amount, according to Box and Behnken design

\begin{tabular}{ccccccc}
\hline Point of experiment & $\begin{array}{c}\text { AA } \\
(\mathbf{m g} / \mathbf{k g})\end{array}$ & $\begin{array}{c}\text { TG } \\
(\mathbf{m g} / \mathbf{k g})\end{array}$ & $\begin{array}{c}\text { MG } \\
(\%)\end{array}$ & $\begin{array}{c}\text { Volume } \\
(\mathbf{m l})\end{array}$ & $\begin{array}{c}\text { Firmness, } \\
(\mathbf{g} * \mathbf{s e c})\end{array}$ & $\begin{array}{c}\text { Overall } \\
\text { acceptability }\end{array}$ \\
\hline 1 & 5 & 0 & 15 & 66.36 & 23607 & 13.8 \\
2 & 0 & 1.5 & 15 & 66.96 & 22182 & 12.3 \\
3 & 5 & 1.5 & 22.5 & 73.54 & 15112 & 14.8 \\
4 & 10 & 0 & 22.5 & 78.01 & 16787 & 15.4 \\
5 & 5 & 3 & 15 & 66.82 & 18597 & 13.2 \\
6 & 10 & 1.5 & 30 & 76.56 & 13134 & 16.5 \\
7 & 10 & 1.5 & 15 & 61.52 & 21680 & 13.8 \\
8 & 5 & 0 & 30 & 78.65 & 14110 & 14.3 \\
9 & 0 & 1.5 & 30 & 75.91 & 17950 & 14.0 \\
10 & 0 & 3 & 22.5 & 78.38 & 16487 & 13.8 \\
11 & 5 & 1.5 & 22.5 & 74.03 & 20217 & 14.5 \\
12 & 5 & 1.5 & 22.5 & 73.79 & 20228 & 14.7 \\
13 & 5 & 3 & 30 & 80.79 & 14028 & 18.3 \\
14 & 0 & 0 & 22.5 & 70.79 & 22365 & 11.5 \\
15 & 10 & 3 & 22.5 & 73.18 & 26436 & 15.1 \\
\hline
\end{tabular}

Table 4.

Regression coefficients and significance of regression models for selected properties of puff pastry made from spelt flour

\begin{tabular}{|c|c|c|c|}
\hline Regression coefficients & Volume (ml) & Firmness (g*sec) & Overall acceptability \\
\hline Intercept & 737.9 & 19.13 & 146.67 \\
\hline $\mathrm{AA}$ & -0.35 & -118.37 & $1.15^{\star \star \star}$ \\
\hline TG & 0.67 & 209.87 & $0.67^{\star \star \star}$ \\
\hline M & $628.12^{* * *}$ & $-2730.50^{\star *}$ & $1.25^{\star \star *}$ \\
\hline$A A^{*} T G$ & $-3.105^{\star \star *}$ & $3881.75^{\star \star}$ & $-0.65^{\star *}$ \\
\hline$A A^{*} M$ & $15.22^{* *}$ & -1078.5 & 0.25 \\
\hline$T G^{*} M$ & 0.42 & 1.982 & $1.15^{\star \star \star}$ \\
\hline$A A^{2}$ & -0.81 & & $0.73^{* *}$ \\
\hline $\mathrm{TG}^{2}$ & 211.04 & & 0.02 \\
\hline$M^{2}$ & $-2.74^{\star * *}$ & & 0.22 \\
\hline${ }^{a} R^{2}, \%$ & 0.985 & 0.723 & 0.982 \\
\hline$P$ value of ${ }^{b} L F$ & 0.63 & 0.84 & 0.10 \\
\hline
\end{tabular}

Table 5.

Criteria for optimization of volume, firmness and overall acceptability of spelt puff pastry

\begin{tabular}{lcccc}
\hline \multicolumn{1}{c}{ Factors } & Goal & Lower limit & Upper limit & Importance \\
\hline Ascorbic acid & in range & 0 & 10 & 3 \\
Transglutaminase & in range & 0 & 3 & 3 \\
Margarine & in range & 15 & 30 & 3 \\
Volume of puff pastry & Maximize & 61.52 & 80.79 & 3 \\
Firmness of puff pastry & Minimize & 13134 & 26436 & 3 \\
Overall acceptability & Maximize & 11.5 & 18.3 & 5 \\
\hline
\end{tabular}

Margarine is an ingredient whose important role in the production of puff pastry made from spelt flour was confirmed in this experiment. As it was mentioned above, margarine increased the volume con- siderably ( $p \leq 0.01$ ), but it also considerably decreased the firmness $(p \leq 0.05)$. According to that, margarine exerted an important positive influence on the overall acceptability of product. The product was 
considerably acceptable $(p \leq 0.01)$ when it had the combination of the ingredients such as margarine and the enzyme transglutaminase, but it was even more acceptable when ascorbic acid was present in the formulation.

However, the square increase in the amount of margarine can result in agglutination of layers of spelt dough, which caused great $(p \leq 0.01)$ decrease in volume.

Regarding different main and interaction effects of the applied ingredients, it is necessary to carry out their optimization by applying the appropriate statistical technique, and to give the suggestion for the optimal recipe for the puff pastry made from spelt flour.

The proposition of the criteria necessary for the determination of optimal amounts of ascorbic acid, transglutaminase and margarine in the production of spelt puff pastry was based upon preliminary experiments and the literature data (Gerrard et al., 2000; Pimdit et al., 2008; Soronja Simovic et al., 2009; Filipčev et al., 2013). These criteria are shown in Table 5.
When the criteria for quality is being set, as it was shown in the Table 5 solutions are got by applying the statistical software and the function of desirability (Table 6).

All 24 solutions had high desirability values from 0.714 to 0.852 . Taking into consideration all optimization solutions for desirability values above 0.80 , the range of concentrations for ascorbic acid, transglutaminase and margarine suitable for spelt puff pastry was defined. Ascorbic acid varied in the concentration range from $3.60 \mathrm{mg} / \mathrm{kg}$ to $10 \mathrm{mg} / \mathrm{kg}$, and transglutaminase from $0.03 \mathrm{mg} / \mathrm{kg}$ to $3 \mathrm{mg} / \mathrm{kg}$. The higher the concentration of the ascorbic acid is, the lower the concentration of transglutaminase is, and vice versa.

The range of the amount of margarine was very narrow, and it varied from 29.84 to $30 \%$ on dough basis. The baker can choose among the shown optimization solutions and will get a desired product with $80 \%$ probability. New experimental baking was done in order to verify the predicted solution under number 22 , and the predicted results were compared with the actual results of baking trial (Table 7).

Table 6.

Predictive solutions

\begin{tabular}{cccccccc}
\hline Sol. & AA & TG & Margarine & Volume & Firmness & $\begin{array}{c}\text { Overall } \\
\text { acceptability }\end{array}$ & Desirability \\
\hline 1 & 3.60 & 3.0 & 30.00 & 81.00 & 17837 & 17.7 & 0.85 \\
2 & 3.52 & 3.0 & 30.00 & 81.03 & 17793 & 17.7 & 0.85 \\
3 & 3.69 & 3.0 & 30.00 & 80.98 & 17884 & 17.7 & 0.85 \\
4 & 3.45 & 3.0 & 30.00 & 81.04 & 17759 & 17.7 & 0.85 \\
5 & 3.66 & 2.99 & 30.00 & 80.93 & 17858 & 17.7 & 0.85 \\
6 & 3.15 & 2.99 & 30.00 & 81.09 & 17593 & 17.6 & 0.85 \\
7 & 2.81 & 3.0 & 30.00 & 81.22 & 17412 & 17.5 & 0.85 \\
8 & 3.90 & 3.0 & 29.84 & 80.89 & 18008 & 17.7 & 0.85 \\
9 & 2.42 & 2.89 & 30.00 & 80.79 & 17189 & 17.2 & 0.84 \\
10 & 1.25 & 3.00 & 30.00 & 81.52 & 16577 & 17.0 & 0.84 \\
11 & 10.00 & 0.99 & 30.00 & 78.62 & 13134 & 16.40 & 0.83 \\
12 & 9.96 & 0.99 & 30.00 & 78.63 & 13134 & 16.39 & 0.83 \\
13 & 10.00 & 0.98 & 30.00 & 78.65 & 13080 & 16.39 & 0.83 \\
14 & 10.00 & 1.02 & 30.00 & 78.57 & 13238 & 16.42 & 0.83 \\
15 & 9.87 & 0.97 & 30.00 & 78.65 & 13133 & 16.38 & 0.83 \\
16 & 10.00 & 0.97 & 29.90 & 78.63 & 13133 & 16.37 & 0.83 \\
17 & 10.00 & 1.07 & 30.00 & 78.44 & 13462 & 16.46 & 0.83 \\
18 & 10.00 & 0.52 & 30.00 & 79.92 & 11222 & 16.04 & 0.82 \\
19 & 10.00 & 1.32 & 29.99 & 77.97 & 14472 & 16.66 & 0.82 \\
20 & 10.00 & 1.37 & 30.00 & 77.88 & 14675 & 16.69 & 0.82 \\
21 & 10.00 & 1.45 & 30.00 & 77.77 & 14981 & 16.76 & 0.81 \\
$\mathbf{2 2}$ & $\mathbf{1 0 . 0 0}$ & $\mathbf{0 . 0 3}$ & $\mathbf{3 0 . 0 0}$ & $\mathbf{8 1 . 6 9}$ & $\mathbf{9 2 5 5}$ & $\mathbf{1 6 . 6 6}$ & $\mathbf{0}$ \\
23 & 8.90 & 1.89 & 30.00 & 77.55 & 16805 & 17.12 & 0.79 \\
24 & 10.00 & 0.00 & 23.81 & 78.38 & 13909 & 15.14 & 0.71 \\
\hline
\end{tabular}


Table 7.

Comparison of the prediction values and the actual values for the selected optimization solution

\begin{tabular}{|c|c|c|c|c|c|c|}
\hline & $\begin{array}{c}\mathrm{AA} \\
\mathrm{mg} / \mathrm{kg}\end{array}$ & $\begin{array}{c}\mathrm{TG} \\
\mathrm{mg} / \mathrm{kg}\end{array}$ & $\begin{array}{l}\mathbf{M} \\
\%\end{array}$ & $\begin{array}{c}\mathrm{V} \\
(\mathrm{ml})\end{array}$ & $\underset{(\mathbf{g} \times \mathbf{s})}{\mathbf{F}}$ & OA \\
\hline & \multicolumn{3}{|c|}{ Desirability: $80 \%$} & \multicolumn{3}{|c|}{ Predicted values } \\
\hline \multirow[t]{2}{*}{$\begin{array}{l}\text { Selected optimization } \\
\text { solutions (No 22) }\end{array}$} & \multirow{2}{*}{10.0} & \multirow{2}{*}{0.03} & \multirow{2}{*}{30.0} & 81.69 & $\begin{array}{l}9255 \\
\text { tual ve }\end{array}$ & 16.7 \\
\hline & & & & 80.75 & 9348 & 17.1 \\
\hline
\end{tabular}

The predictive solution $22(10 \mathrm{mg} / \mathrm{kg} \mathrm{AA}$, $0.03 \mathrm{mg} / \mathrm{kg} \mathrm{TG}$ and $30 \%$ margarine on dough basis) was chosen because it gave the greatest value to volume $(81.69 \mathrm{ml})$, the lowest value to firmness (9255 $\mathrm{g} * \mathrm{~s}$ ) and high value to the overall acceptability (16.66). Apart from that, this formulation is more payable economically because the price of the ascorbic acid is lower than the price of transglutaminase, and the present concentration of the ascorbic acid is higher than the one of the already mentioned enzyme.

Predicted values were close to the experimental results indicating that the models were adequate to predict these parametars.

\section{CONCLUSION}

The obtained results justified the enforcement of spelt flour in the production of non-yeasted puff pastry. To produce puff pastry from $100 \%$ spelt flour, the addition of ingredients with oxidation reaction such as ascorbic acid and transglutaminase is necessary. Their amounts varied from $3.60 \mathrm{mg} / \mathrm{kg}$ to $10 \mathrm{mg} / \mathrm{kg}$ and from 0.03 $\mathrm{mg} / \mathrm{kg}$ to $3 \mathrm{mg} / \mathrm{kg}$, respectively. The interaction effect of the ascorbic acid and transglutaminase is important for the characteristics of spelt puff pastry. It seems that the amounts of these two ingredients are inversely proportional which means that with the addition of the greater amount of ascorbic acid, the amount of transglutaminase should be decreased, and vice versa. The amount of margarine used for the spelt puff pastry should be at the level of $30 \%$ on dough basis. The amount of margarine has an important influence on the increase of the volume and overall acceptability, as well as on the decrease of firmness of puff pastry. By verification of one optimal predictive for- mulation which consisted of $10 \mathrm{mg} / \mathrm{kg}$ of ascorbic acid, $0.03 \mathrm{mg} / \mathrm{kg}$ transglutaminase and $30 \%$ of margarine on dough basis, the product with maximal volume and minimal firmness was obtained.

\section{ACKNOWLEDGEMENTS}

This paper is a result of the research within the project III 46005 financed by the Ministry of Education, Science and Technological Development, Republic of Serbia.

\section{REFERENCES}

1. AACC (1995). Approved Methods of the American Association of Cereal Chemists $9^{\text {th }}$ Ed., AACC Inc., St Paul, MN, AACC methods 18-01, 38-10, 44-9, 4612 , and $54-21$.

2. Abdel-Aal E.S.M., Hucl P., Sosulski F.W. (1998). Food uses for ancient wheats. Cereal Foods World, 43 (6), 763-767.

3. Bakal, A.I. 1991. Fat reduction in baked goods, In Fat and Cholesterol Reduced Foods: Technologies and Strategies. Eds. Chuck Haberstroh and Charles E. Morris. Portfolio Publishing Company, Houston, pp. 185-190.

4. Bessler, T.R., Ortheoefer, F.T. (1983). Providing lubricity in food fat systems. Journal of the American Oil Chemist's Society, 60 (6), 1765-1768.

5. Bojnanská T., Francáková H. (2002). The use of spelt wheat (Triticum spelta L.) for baking applications. Rostl. Výr., 48 (2), 41-147.

6. Box, G.E.P., Benhken, D.W. (1960). Some new three level designs for the study of quantitative variables. Tachometric, 2, 455-475.

7. Derringer, G.C., Suich, R. (1980). Simultaneous optimization of several response variables. Journal of Quality Technology, 12, 214-219.

8. Filipčev, B. (2014). Texture and stress relaxation of spelt-amaranth composite breads. Food and Feed Research, 41 (1), 1-9.

9. Filipčev, B., Bodroža-Solarov, M., Brkljača, J. (2012). Characterization of organically grown spelt cultivars for cracker-making applications. Food and Feed Research, 39 (2), 61-68.

10. Filipčev, B., Šimurina, O., Bodroža-Solarov, M., Obreht, D. (2013). Comparison of the bread-making performance of spelt varieties grown under organic conditions in the environment of northern Serbia and their responses to dough strengthening improvers. Hemijska industrija, 67 (3), 443-453. 
11. Gerrard, J.A., Newberry, M.P., Rossa, M., Wilson, A.J., Fayle, S.E., Kavale, S. (2000). Pastry lift and croissant volume as affected by microbial transglutaminase. Food Engineering and Physical properties, 65 (2), 312-314.

12. Hay, R.L. (1993). Effect of flour quality characteristics on puff pastry baking performance. Cereal Chemistry, 70 (3), 392-396.

13. Lefébure, E., Ronkart, S., Brostaux, Y., Béra, F., Blecker, C., Danthine, S. (2013). Investigation of the influence of processing parameters on physicochemical properties of puff pastry margarines using surface response methodology. Food Science and Technology LWT, 51 (2), 225-232.

14. Marconi E., Carcea M., Schiavone M., Cubadda R. (2002). Spelt (Triticum spelta L.) pasta quality: Combined effect of flour properties and drying conditions. Cereal Chemistry, 79, 634-639.

15. Mc Gill, E.A. (1981). A closer look at bakery fats. In Puff Pastry Faults. Ed. E.A. Mcgill, Puff Pastry Faults Peerless, Food Products, Liverpool, 14.

16. Pimdit, K., Therdthai, N., Jangchud, K. (2008). Effects of fat replacers on the physical, chemical and sensory characteristics of puff pastry. Kasetsart Journal (Natural Science), 42 (6), 739-746.

17. Schober T.J., Clarke C.I., Kuhn M. (2002). Characterization of functional properties of gluten proteins in spelt cultivars using rheological and quality factor measurements. Cereal Chemistry, 79 (3), 408417.

18. Soronja Simović, D., Pajin, B., Seres, Z., Filipović, N. (2009). Effect of low-trans margarine on physic-chemical and sensory properties of puff pastry, International Journal of Food Science and Technology, 44 (2), 1235-1244

19. Taylor, S. L. (1985). The addition of gluten to pastry flours. In FMBRA Bulletin. Chipping Campden. UK: Campden BR, 2, 51-57.

20. Wassell, P., Young, N.W.G. (2007). Food applications of trans fatty acid substitutes. International Journal of Food Science and Technology, 42 (4), 503-517.

21. Wickramarachchi, K.S., Sissons, M.J., Cauvain, P.S. (2015). Puff pastry and trends in fat reduction: an update. International Journal of Food Science and Technology, 50 (11), 1065-1075.

\title{
ЕФЕКАТ АСКОРБИНСКЕ КИСЕЛИНЕ, ТРАНСГЛУТАМИНАЗЕ И КОЛИЧИНЕ МАРГАРИНА НА КВАЛИТЕТ ПРОИЗВОДА ОД ЛИСНАТОГ ТЕСТА ПРОИЗВЕДЕНОГ ОД БРАШНА СПЕЛТА ПШЕНИЦЕ
}

\author{
Оливера Д. Шимурина ${ }^{1 *}$, Бојана В. Филипчев ${ }^{1}$, Марија И. Бодрожа-Соларов ${ }^{1}$, \\ Драгана М. Шороња-Симовић
}

\author{
${ }^{1}$ Универзитет у Новом Саду, Научни институт за прехрамбене технологије у Новом Саду, \\ Булевар цара Лазара 1, 21000 Нови Сад, Србија \\ ${ }^{2}$ Универзитет у Новом Саду, Технолошки фракултет, Булевар цара Лазара 1, 21000 Нови Сад, \\ Србија
}

\begin{abstract}
Сажетак: Производи од лиснатог теста имају нежну и пахуљасту структуру која настаје јединственом комбинацијом масноће и теста. Ови пекарски производи су направљени од танких листова теста неизменично одвојени листовима маргарина и зато се сматрају храном са високим садржајем масноће. Особине производа од лиснатог теста највише зависе од квалитета брашна које мора бити наменско. У производњи производа од лиснатог теста најчешће се користи бело пшенично брашно. У последње време захтеви потрошача за здраве пекарске производе имају велики одзив у пекарској индустрији. На тржишту су присутни нови производи од сировина које имају високу нутритивну вредност. У раду је презентована оптимизација формулације производа од лиснатог теста направљеног од брашна спелта пшенице варирањем количине састојака као што су: маргарин, аскорбинска киселина и ензим трансглутаминаза. Оптималан однос ових сировина заснива се на њиховим главним и интеракцијским ефректима. Током оптимизације квалитета лиснатог теста од спелте постављени су следећи циљеви: максимална запремина, минимална чврстоћа и максимална општа прихватљивост. Оптимална решења су у опсегу концентрација аскорбинске киселине од $3,60 \mathrm{mg} / \mathrm{kg}$ до $10 \mathrm{mg} / \mathrm{kg}$, трансглутаминазе од 29,84 до $30 \%$ и маргарина од $29,84 \%$ до $30 \%$ на масу теста. Препоручује се да фрормулација лиснатог теста од спелте укључи: аскорбинску киселину у количини од $10 \mathrm{mg} / \mathrm{kg}$, трансглутаминазу $0.03 \mathrm{mg} / \mathrm{kg}$ и маргарин 30\% на масу теста да би се добио производ жељених карактеристика.
\end{abstract}

Кључне речи: спелта, лиснато тесто, аскорбинска киселина, трансглутаминаза, оптимизација

Received: 5 November 2015 